\title{
The influence of natural fiber reinforcement on the mechanical properties of polyolefin-based hybrid composites
}

\section{Doğal lif takviyesinin poliolefin bazlı hibrit kompozitlerin mekanik özellikleri üzerindeki etkisi}

\author{
Ayça Şahika SSAHIN $1^{*}$ ID , Sami SAYER ${ }^{2}$ iD \\ ${ }^{1}$ Institute of Science and Technology, Ege University, İzmir, Turkey. \\ aycasahikasahin@gmail.com \\ 2Department of Polymer Technology, Ege Vocational School, Ege University, İzmir, Turkey. \\ samisayer@hotmail.com
}

\begin{abstract}
In this study, effects of natural fiber reinforcement on mechanical properties of polyolefin based hybrid composites widely used different industrial areas were investigated. In this context, jute - PP composites having different jute ratios are produced in twin screw extruder on first stage of production. In the second stage, the films are produced at 450 $\mu \mathrm{m}$ thickness of PP material with different jute ratios are placed between HDPE (S 0464) plates with a thickness of $1 \mathrm{~mm}$ and are pressed under a pressure of 8.163 bar and temperature of $190{ }^{\circ} \mathrm{C}$ and consequently hybrid polyolefin composite sheets are obtained. The improvement of mechanical strength of hybrid composite material is realized $8.6 \%$ ratio as $18.41 \mathrm{MPa}$ in 5\% jute reinforced hybrid composite. As a result of FTIR characterization, it is observed that the interface agents affecting the mechanical strength positively are significant. When SEM analysis of fracture surfaces formed after tensile test is performed, it is determined that an effective interface is formed between the fiber and the polymer, wheras the fibers that change direction due to production methods adversely affected the mechanical strength.
\end{abstract}

Keywords: Polyolefin, Hybrid composite sheets, Jute fiber, Mechanical properties.

\section{Introduction}

Nowadays, many research has focused on natural fiberreinforced thermoplastic composites in the last decade, with the rise of global environmental problems today, and researchers and engineers focused on biologically based materials in the design and production of composite materials. The reasons for the rapid expansion of plastic materials that began to be developed in the early 20th century are low density and light weight, easy forming, surface quality and good corrosion resistance. Plastic materials, which could not provide sufficient mechanical properties when used alone, are started to be used by reinforcing them with various materials in the 1940 s, thus resulting in polymer matrix composites [1]. In particular, the growing interest in polyolefin-based natural fiber reinforced composites is increasing day by day. It is preferable that they are low density materials which allow the production of very lightweight composite materials with highly specific properties.
Öz

Bu çalıșmada, endüstrinin farklı alanlarında yaygin olarak kullanılan poliolefin esasl malzemelerde doğal elyaf katkısının malzemenin mekanik özelliklerine etkisi araștırılmıştır. Bu kapsamda, ilk etapta çift vidal ekstrüderde farkl jüt oranlarında PP kompozit malzeme üretilmisțtir. İkinci aşamada ise farkl jüt oranlarındaki PP malzemeden 450 um kalınlığında üretilen filmler, kalınlığı 1 mm olan HDPE (S 0464) levha arasına yerleștirilerek $190{ }^{\circ} \mathrm{C}$ sicaklikta ve 8.163 bar basinc altında preslenerek hibrit yapıda poliolefin kompozit levhalar elde edilmiștir. Hibrit kompozit malzemenin mekanik dayanımındaki iyileșme \%8.6 oranında, \%5 jüt takviyeli hibrit kompozitte $18.41 \mathrm{MPa}$ olarak gerçekleșmistir. Sonuc olarak, FTIR karakterizasyonunda arayüz maddelerinin mekanik mukavemeti olumlu yönde etkilediği görülmüstür. Cekme testi sonrası olușan kırılma yüzeylerine SEM analizi yapıldığında elyaf ve polimer arasında etkin bir arayüz oluștuğu, ancak üretim tekniğinden dolayı yön değiştiren elyafların mekanik mukavemeti olumsuz yönde etkilediği saptanmıștır.

Anahtar kelimeler: Poliolefin, Hibrit kompozit plakalar, Jüt lifi, Mekanik özellikler.

As a result of sanctions to reduce emissions, the interest in natural, environment-friendly and renewable materials have attracted the attention of researchers, especially the Kyoto protocol. In this context, in the automotive industry, the use of natural fibers with low mechanical costs/weight ratios and low cost for reducing the emission values of vehicles is becoming widespread [2].

The use of bio-based fibers in thermoplastic composites is becoming more and more important as they are renewable and environmentally friendly. Jute is one of the most versatile and versatile agro fiber with various applications [3]. Fiberreinforced thermoplastic composites have been superior to traditional materials, making them the most suitable materials for the automobile and electrical industry with their ease of processing, rapid production cycle and low tonnage cost [4]. These composites can be designed to be produced under different static and dynamic conditions [5].

In 2003, approximately 43.000 tons of natural fibers are used as reinforcement materials in European Union countries. By 2010 , this amount reached 315.000 tons, accounting for $13 \%$ of

${ }^{*}$ Corresponding author/Yazışılan Yazar 
the total reinforcing materials (glass, carbon and natural fiber). In 2020, this amount is estimated to be approximately 830.000 tons, and reinforcement is expected to account for $28 \%$ of the total. The United States stated that by 2020 , they aim at least 10 $\%$ of all basic chemical structures and $50 \%$ by 2050 to be formed from renewable and plant-based resources. In the coming years, it is predicted that bio-composites will find wide use as a new generation structural materials and this has led to a rapid increase in studies in this field [6].

Research with natural fibers such as jute, flax and hemp has shown that natural fibers can be preferred as an effective reinforcing element for composite materials. In addition to being renewable and environment-friendly; processing methods compared to synthetic fibers offer advantages and benefits in terms of cost [7]. These features offer the opportunity to research and develop natural fibers for applications in the packaging, automotive and construction industries to create a new product market. However, the relatively low mechanical properties of products made from natural fibers have limited them to use in non-structural and infrastructure applications. By performing different studies in the form of chemical or physical alteration of the matrix, fiber or both components together; it has been tried to increase the mechanical properties of natural fiber reinforced composites [8].

Jute fiber like other bio-based lignocellulosic fibers, is hygroscopic in nature and is therefore not readily compatible with hydrophobic thermoplastics such as polypropylene (PP) and polyethylene (PE) [3]. Many studies have been conducted to increase the interaction between natural fiber and polymer matrix. A weak adhesion results in a weak charge transfer from fiber to matrix creating a low binding effect [9],[10]. In order to reduce the hydrophilic character of natural fibers and improve the adhesion properties, a chemical modification of their surface is required. Alkali treatment [11],[12], the use of maleic anhydride copolymers [13],[14], fiber impregnation [15] and several methods have been proposed to modify natural fiber surfaces such as the use of silane [16]-[19].

The purpose of this study is to improve the adhesion between fiber and matrix by applying surface modification to natural fibers with low mechanical properties. In addition, due to its low cost, easy formability and corrosion resistance in different production sectors, fiber reinforcement from PP and HDPE materials is preferred. Producing a new composite material with superior mechanical properties than PP and HDPE material.

\section{Materials and methods}

This study consists of three stages. In the first stage of production of granular composite material is made in extrusion machine by reinforcing jute from natural fibers and PP used as matrix material from thermoplastics. Mechanical properties of the material are examined by producing pull rods on the injection machine.

In the second stage, the film is extruded from jute reinforced PP granules in a twin screw extruder. With the goal of improving interface adhesion; jute fibers are treated in silane solution. During granule production, maleic anhydride acid solution is added to the samples to be reinforced with jute. Jute reinforced $(1.25 \%, 2.5 \%, 5 \%)$ PP films are tested for their mechanical properties by tensile tests.

In the third stage, the production of hybrid composite material is aimed by placing the jute reinforced PP composite films between HDPE sheets. The combination is in the form of HDPE sheet, jute reinforced PP film, HDPE sheet. Maleic anhydride acid solution is applied between plates to improve interfacial adhesion. Hybrid composite plates are manufactured by combining with hydraulic press at $190^{\circ} \mathrm{C}$ and $100 \mathrm{kN}$ load. The process flow diagram of the production stages is given in Figure 1.

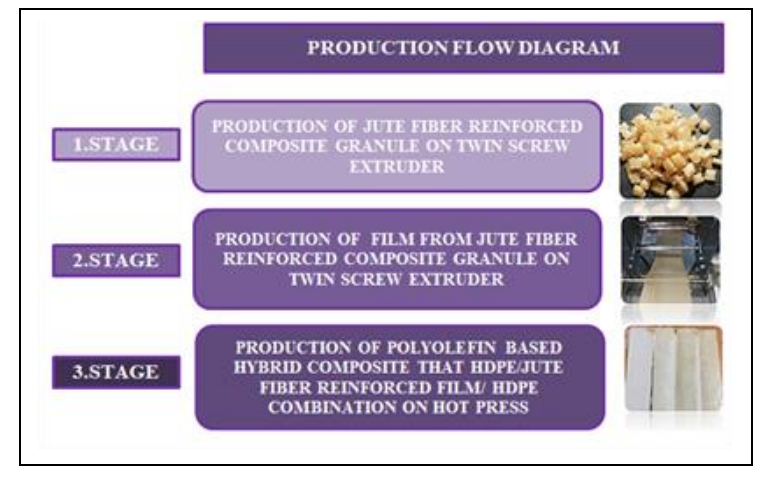

Figure 1. Production flow diagram.

All samples coding according to the reinforcement ratio was performed with system that are shown in Table 1.

Table 1. Samples definition.

\begin{tabular}{cccc}
\hline $\begin{array}{c}\text { Jute } \\
\text { Ratio } \\
(\%)\end{array}$ & $\begin{array}{c}\text { Injection/Extrusion } \\
\text { Granule/Solid } \\
\text { Product } \\
\text { (PP+jute) }\end{array}$ & $\begin{array}{c}\text { Extrusion } \\
\text { Film } \\
\text { (PP+jute) }\end{array}$ & $\begin{array}{c}\text { Hot Press } \\
\text { Hybrid } \\
\text { Composite } \\
\text { (HDPE+PP+jute) }\end{array}$ \\
\hline 0 & J0 & JP0 & JPE0 \\
1.25 & J1 & JP1 & JPE1 \\
2.5 & J2 & JP2 & JPE2 \\
5 & J3 & JP3 & JPE3 \\
\hline
\end{tabular}

\subsection{Production stage-1}

In this stage, jute fibers (10-canvas: 311 grams/yard $\left.{ }^{2}\right)$ supplied from Ege Çuval company are used as reinforcement in the composite material production. These yarns areprovided from the jute bag edge are divided into yarns of 15-18 mm length. By applying 2 bar pressure to the jute yarns placed in a closed container; yarns are converted to jute fibers (Figure 2).

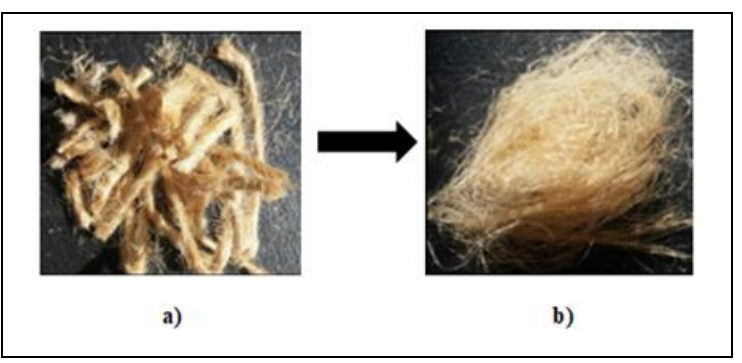

Figure 2. (a): 15-18 mm jute yarns. (b): Jute yarns of applied air pressure.

MH 418 polypropylene from PETKIM is used as the matrix material. PP granules are powdered by grinding (Figure 3 ).

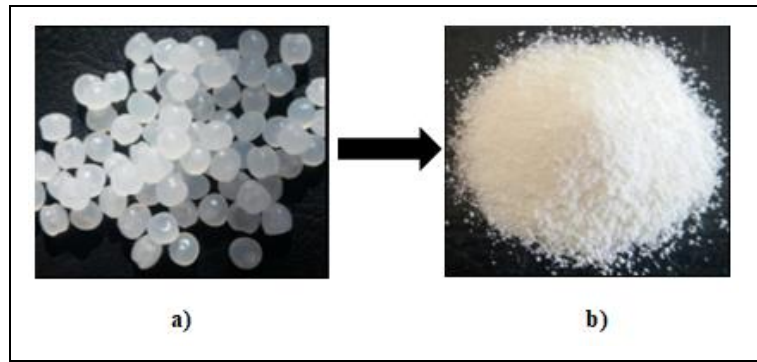

Figure 3. (a): MH 418 PP granules. (b): PP on powder form. 
The layers (oils, waxes, etc.) on the surface of the jute fibers are removed in the laboratory $\left(23^{\circ} \mathrm{C}, 50 \% \mathrm{RH}\right)$ for 2 hours in $2 \%$ $\mathrm{NaOH}$ solution from Merck. Then, it is dried in a drying-oven at $50^{\circ} \mathrm{C}$ for 24 hours. In order to provide maximum adhesion at the PP and jute interface, the jute fibers dried in the previous step are allowed to stand in $0.3 \%$ Silane (Dow Corning, product code Z-6030) for 2 hours. Maleic anhydride acid is supplied from Sigma Aldrich as the coupling agent. 0.3 wt \% maleic anhydride acid solution is added to the mixture, during the production of jute reinforced PP granules. Jute fiber reinforced PP granules are produced at APV Baker Perkins MP30 model twin screw extruder in Uçar Plastik Company. The screw diameter is $30 \mathrm{~mm}$, the $\mathrm{L} / \mathrm{d}$ ratio is 25 and the screw speed is $150 \mathrm{rpm}$. The operating temperature of the machine is set to $170{ }^{\circ} \mathrm{C}$.

After passing through the cylinder, Granules are produced in the form of string composite by cutting. Granule samples produced in the first step are identified as J0, J1, J2 and J3. J0 (MH 418 PP) and J1, J2, J3 (3 types of samples) which are respectively $1.25 \%, 2.5 \%$ and $5 \%$ are produced. The granules obtained as a result of sample production (Figure 4) are as follows:

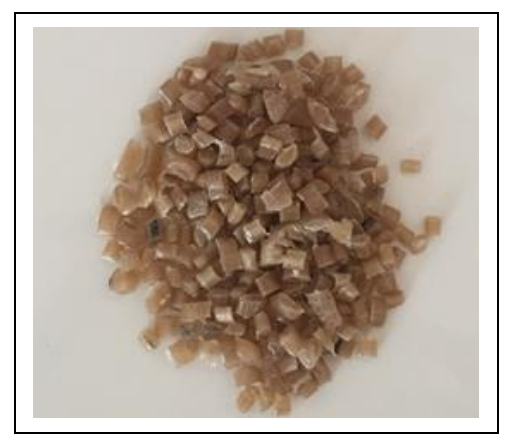

Figure 4. Jute fiber reinforced granule composite.

\subsection{Production stage-2}

In the second stage of production, it is aimed to make the jute reinforced PP granules suitable for hybrid composite production. The granules are filmed by twin screw extruder (Lab Tech Engineering Company Ltd.) with the model number LUMCR-50.

The die setting was adjusted to produce a sample width of 450 microns and $70 \mathrm{~mm}$. The heating chamber is set at $184^{\circ} \mathrm{C}$. After a short period of material vomiting during the first exit from the mold, composite is filmed without quality problems. The MH 418 PP granules are produced in the same machine setting as the three composite jute reinforced PP composite granules (Figure 5). The samples produced in the second step are identified by the JP code, namely jute reinforced PP. According to the jute reinforcement ratio, it is called JP0, JP1, JP2 and JP3 respectively. During production, the production is carried out without a quality defect, despite the possibility of damaging the film as the reinforcing ratio increased due to the jute fiber used.

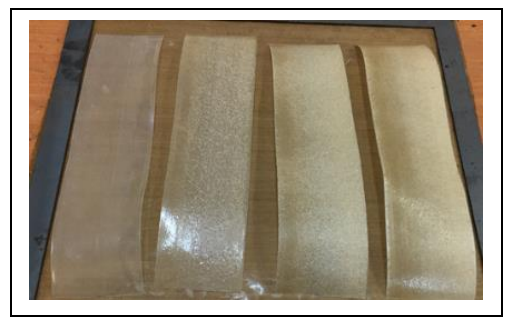

Figure 5. Jute reinforced PP composite film samples.

\section{$2.3 \quad$ Production stage-3}

In the third stage of the research, jute reinforced/nonreinforced PP films are pressed under temperature with HDPE sheets. Samples are produced at this stage are identified by the "JPE" code Table 1 with involves the contents of the samples.

The HDPE material which is supplied from Türkay Plastik and whose raw material is S 0464 coded by PETKIM is used. Polyethylene plates are supplied in $1 \mathrm{~mm}$ thickness and $1 \mathrm{~m}^{2}$ that are cut as $300 \mathrm{~mm}$ length and $70 \mathrm{~mm}$ width.

Jute fiber reinforced PP granules and MH418 PP raw material granules are cut into $300 \mathrm{~mm}$ length and $70 \mathrm{~mm}$ width as in polyethylene sheet after being filmed. The HDPE plates are placed in $0.1 \%$ by mass of $\mathrm{NaOH}$ solution is supplied by Merck for 2 hours to remove oil and wax from the surface. Drying is allowed for 2 hours.

Fontijne Grotnes brand LabEcon series hydraulic press is used for the production of hybrid plates. Teflon paper is used to prevent 4 different samples to be placed in this mold from sticking to the press surfaces.

The thickness of the die made of cold working tool steel is $2 \mathrm{~mm}$ and the internal dimensions are $350 \mathrm{~mm} \times 350 \mathrm{~mm}$. During the process, the press surface is coated with Teflon to prevent the HDPE sheets from sticking to the die surface. After the molding and teflon paper placement is completed and then the HDPE sheets are placed on a clean surface for each sample. $0.3 \% \mathrm{w} / \mathrm{w}$ maleic anhydride acid solution supplied by Sigma Aldrich to provide maximum interfacial adhesion between HDPE plates on both surfaces where these sheets come into contact with jute reinforced PP composite film. After the application of maleic anhydride to the surface of the HDPE plate, this process was applied to both surfaces of the composite film material. The film on the HDPE plate is placed on the plate. Then, maleic anhydride acid solution is applied to the surface of the 2.HDPE plate to be placed on the film and HDPE plate is placed.

The 3-layer hybrid composite is placed in the hydraulic press after the interface process is applied in the same way for 4 types of samples. Chemical bonding and adhesion are occured without reducing the adhesion strength obtained with the interface. Maleic anhydride acid which is applied between PE plate and jute reinforced PP composite film is predicted to be a production defect which may create air bubbles during adhesion and make a gap and decrease the strength.

The press is applied at a force of $100 \mathrm{kN}$. The temperature to which the samples will be exposed is $190{ }^{\circ} \mathrm{C}$ for the top and bottom plates. The set points at the specified temperature and strength are applied for 35 minutes. The samples are allowed to cool in the press for 24 hours. After 24 hours of cooling, the samples are melted into a whole plate. The samples are cut by sawing machine and the production is completed.

\section{Test and characterization}

\subsection{Determination of density}

The density of the granular plastic material is measured by measuring the weight first in air and then in the specific alcohol, and then testing the density of the material.

The density meter is determined at laboratory temperature using a balance (ISO 1183). AND GR-200 was used as a balance. The values of the three samples on the basis of random granules and the values obtained from the technical information of PP MH 418 and PE S 0464 materials are given in Table 2.

The filling/reinforcing ratio of the material effects all its properties, especially mechanical properties. According to the 
results of the analysis, as the reinforcement ratio of the material increases, the density decreases.

Table 2. Density values of samples.

\begin{tabular}{cc}
\hline Sample Code & Density $\left(\mathrm{g} / \mathrm{cm}^{3}\right)$ \\
\hline PP MH 418 & 0.9058 \\
PE S 0464 & 0.9365 \\
J1 & 0.8895 \\
J2 & 0.8810 \\
J3 & 0.8796 \\
\hline
\end{tabular}

\subsection{MFI (Melt Flow Indexer)}

MFI is a value that indicates how much material flows in $\mathrm{g} / 10$ min which determines the fluidity of the material under certain temperature and pressure $\left(190^{\circ} \mathrm{C}\right.$ and $2.16 \mathrm{~kg}$ in this test) in accordance with ISO 1133 standards. It plays an important role in the processing and molding of the material. The MFI is inversely proportional to the viscosity of the melt under the test conditions, but it should not be ignored that the viscosity depends on the applied force.

The granules that are obtained at the end of the extrusion are placed in the chamber of the device which is brought to the desired temperature $\left(190^{\circ} \mathrm{C}\right)$ beforehand. Then with the help of the piston melt material starts to flow. The material flowing between the two lines in the piston is weighed. MFI-2322S model JJ-Test Melt Flow Indexer is used for testing in Ege Vocational School Polymer Technology Laboratory. The results of 5 types of sample measurements are given in Table 3:

Table 3. MFI values of samples.

\begin{tabular}{cc}
\hline Sample Code & MFI (g/10min) \\
\hline PP MH 418 & 4.7 \\
PE S 0464 & 0.36 \\
J1 & 6.56 \\
J2 & 8.06 \\
J3 & 10.13 \\
\hline
\end{tabular}

\subsection{Tensile test}

Mechanical properties of the same material vary considerably depending on the production method in polymer based materials. Grellman and Seidler (2015), PA6 GF30 type of material obtained by different production techniques have proven that the mechanical strength values of the samples. The production of PA6 GF30 material by injection molding method, the maximum stress of the tensile sample is $145 \mathrm{MPa}$; It was observed that $90 \mathrm{MPa}$ from the plate produced by extrusion molding method and $55 \mathrm{MPa}$ in the sample taken perpendicular to the production direction. This shows that the mechanical strength values of all polymer based materials may vary depending on the production technique and the way of sampling [20].

Tensile testing experiments are carried out in three groups according to the production stage. Tensile testing was carried out according to ISO EN 527 standard. Depending on the production methods, the geometries of tensile test specimens are defined in the ISO EN 527 standard. Accordingly, there are 1A, 2 and $5 \mathrm{~A}$, geometry 2 used for specimen in the first stage of this study.

\subsubsection{Tensile test of production stage-1}

In this stage, tensile specimens are produced by injection machine Dr BOY $50 \mathrm{~T}$ at $180{ }^{\circ} \mathrm{C}$ in Ege Vocational School Polymer Technology Laboratory. Type $1 \mathrm{~A}$ according to ISO EN 527 is used as the specimen. Test specimen that is produced by injection machine.
Tensile tests are applied at Shimadzu AG-100 model at $50 \mathrm{~mm} / \mathrm{min}$ speed in Dokuz Eylül University laboratory. 1.25\% jute reinforced raw material is not produced in the first stage of production. The tensile test results obtained are shown in Table 4.

Table 4. Tensile test results of granule materials.

\begin{tabular}{cccc}
\hline $\begin{array}{c}\text { Sample } \\
\text { Code }\end{array}$ & $\begin{array}{c}\text { Max Force } \\
(\mathrm{N})\end{array}$ & $\begin{array}{c}\text { Max. Stress } \\
(\mathrm{MPa})\end{array}$ & $\begin{array}{c}\text { Max.Elong. } \\
(\%)\end{array}$ \\
\hline PP MH 418 & 629 & 19.8 & 11.9 \\
Powder PP & 890.6 & 28.3 & 7.9 \\
J1 & - & - & - \\
J2 & 929.9 & 29.4 & 6.9 \\
J3 & 933.7 & 29.6 & 5.5 \\
\hline
\end{tabular}

\subsubsection{Tensile test of production stage-1}

Film samples are used according to ISO EN 527 standards by giving Type $5 \mathrm{~A}$ shape. In the laboratory of Dokuz Eylül University Shimadzu AG-100 model tensile test device is performed. The samples are pulled from the jaws at a speed of $50 \mathrm{~mm} / \mathrm{min}$ and the tests are performed. Before starting the test, tensile elasticity modulus values can be calculated automatically by entering cross-sectional area and first length values to tensile tester.

The thickness of the jute fiber reinforced composite plate is approximately $450 \mu \mathrm{m}$. After each sample is measured one by one during the test, the data is entered into the drawing bench. The test results are shown in Table 5. The values are averaged for all 3 test samples made of jute/PP composite film material. According to the tensile test results, as the reinforcement ratio increases, maximum stress, breaking stress and breaking elongation are observed from mechanical properties. There is an increase in elasticity modulus.

Table 5. Tensile test results of film materials

\begin{tabular}{ccccc}
\hline $\begin{array}{c}\text { Sample } \\
\text { Code }\end{array}$ & $\begin{array}{c}\text { Max } \\
\text { Force } \\
(\mathrm{N})\end{array}$ & $\begin{array}{c}\text { Max. } \\
\text { Stress } \\
(\mathrm{MPa})\end{array}$ & $\begin{array}{c}\text { Max. } \\
\text { Elongation } \\
(\%)\end{array}$ & $\begin{array}{c}\text { Elasticity } \\
\text { Modulus } \\
(\mathrm{MPa})\end{array}$ \\
\hline JP1 & 69.77 & 27.04 & 2.64 & 10.56 \\
JP2 & 68.66 & 26.57 & 2.63 & 10.70 \\
JP3 & 64.55 & 25.02 & 2.17 & 12.15 \\
\hline
\end{tabular}

In order to make a comparison with the material to be produced in the third stage, PE S 0464 material is subjected to tensile test (Table 6). It is applied at a speed of $50 \mathrm{~mm} / \mathrm{min}$ on WDW-5 HENSGRAND model drawing device which is located in Ege Vocational School Polymer Technology Laboratory.

Table 6. Tensile test results of HDPE sheet.

\begin{tabular}{ccc}
\hline $\begin{array}{c}\text { Sample } \\
\text { Code }\end{array}$ & $\begin{array}{c}\text { Max Stress } \\
(\mathrm{MPa})\end{array}$ & $\begin{array}{c}\text { Max. Elongation } \\
(\%)\end{array}$ \\
\hline PE S0464 & 17.6 & 492 \\
\hline
\end{tabular}

\subsection{Tensile test of production stage-3}

Stage-3 specimens are cut into DARDI DWJ2040 Fying Arm Water Jet CNC Cutter Machine in İzmir Waterjet Company as Type 2 geometry according to ISO EN 527 standards. The specimens are pulled from the device jaws at a speed of $50 \mathrm{~mm} / \mathrm{min}$ and the tests are applied.

At least 3 samples are tested for each hybrid composites and the results are averaged. Mechanical properties determined as a result of tensile test are shown in Table 7. According to the tensile test results, while maximum tensile stress decreases, there is no significant change in elastic modulus and elongation at break. 
Table 7. Tensile test results of film materials.

\begin{tabular}{ccccc}
\hline $\begin{array}{c}\text { Sample } \\
\text { Code }\end{array}$ & $\begin{array}{c}\text { Max } \\
\text { Force } \\
(\mathrm{N})\end{array}$ & $\begin{array}{c}\text { Max. } \\
\text { Stress } \\
(\mathrm{MPa})\end{array}$ & $\begin{array}{c}\text { Max. } \\
\text { Elongation } \\
(\%)\end{array}$ & $\begin{array}{c}\text { Elasticity } \\
\text { Modulus } \\
(\mathrm{MPa})\end{array}$ \\
\hline JPE1 & 521.67 & 16.96 & 5.8 & 2.92 \\
JPE2 & 529.04 & 18.03 & 6.23 & 2.89 \\
JPE3 & 544.56 & 18.41 & 6.73 & 2.73 \\
\hline
\end{tabular}

\subsection{FTIR characterization}

The surface modification of the composite material with interfacial agents, during polymerization; In order to see the presence of chemical bonds between interface agents and fiber matrix, FTIR analysis is performed on Perkin Elmer Spectrum Two in EGE-MATAL. The spectrum range of the device is $4000-600 \mathrm{~cm}^{-1}$.

The polyolefin-based hybrid sample is cut to size appropriate for the FTIR device and the joint is separated from the PPcomposite joint with the aid of a utility knife. The analysis is applied for JPE3 sample; because the same chemical interface is used in each sample. This cut sample is then separated from the joint with the PE sheet. This is due to the fact that the chemical bonds between Silane and Maleic Anhydride Acid and the fiber matrix will be formed and the bands can be seen.

In order to estimate the effect of chemical treatment on jute fiber according to Figure 6; PP shows its characteristic peaks at $1452 \mathrm{~cm}^{-1}$ from the symmetrical tensile vibration of the $\mathrm{C}-\mathrm{H}$ bond in $\mathrm{CH} 3$. The characteristic peak at $2839 \mathrm{~cm}^{-1}$ means C-H bonds extending in the methyl and methylene groups in the cellulose and hemicellulose of the treated jute fiber. PP shows its characteristic peaks at $1452 \mathrm{~cm}^{-1}$ from the symmetrical tensile vibration of the $\mathrm{C}-\mathrm{H}$ bond in $\mathrm{CH} 3$. The characteristic peak at $2839 \mathrm{~cm}^{-1}$ means $\mathrm{C}-\mathrm{H}$ bonds extending in the methyl and methylene groups in the cellulose and hemicellulose of the treated jute fiber. The methyl group (-CH 3 ) of lignin binds to the characteristic peak observed at $1375 \mathrm{~cm}^{-1}$. The characteristic peak at $1168 \mathrm{~cm}^{-1}$ indicates that the $\mathrm{Si}-(\mathrm{CHx})$ bond is formed, but not very clearly observed. The presence of $\mathrm{CH}-\mathrm{CH} 2$ and $\mathrm{CH}-\mathrm{CH} 3$ bonds are also observed as characteristic peaks at values of $840 \mathrm{~cm}^{-1}, 809.8 \mathrm{~cm}-1$ and $972 \mathrm{~cm}^{-1}$. No peaks around $1700 \mathrm{~cm}^{-1}$ indicate that no $\mathrm{C}-\mathrm{O}$ bond is formed and that there is no presence of maleic anhydride acid is also not observed. The presence of $\mathrm{CH}-\mathrm{CH} 2$ and $\mathrm{CH}-\mathrm{CH} 3$ bonds are also observed as characteristic peaks at values of $840 \mathrm{~cm}^{-1}, 809.8$ $\mathrm{cm}^{-1}$ and $972 \mathrm{~cm}^{-1}$. No peaks around $1700 \mathrm{~cm}^{-1}$ indicate that no $\mathrm{C}-\mathrm{O}$ bond is formed and that there is no presence of maleic anhydride acid.

\subsection{SEM Characterization}

4 types of hybrid composite materials, macro and micro structures are grouped which tested from fracture surface of hybrid tensile specimen. As the reinforcement ratio increases and the use of the interface agent changes the morphological structure is clearly seen. In the macro images of JPE materials, it is aimed to see the change in the direction of the fibers and increase in fiber ratio as the structure of the new material formed by the combination of PE and PP material and the fiber reinforcement increase as the fiber reinforcement increases.

In the images where the microstructures of the JP materials are present, the realization of the adhesion between the fibers and the matrix is seen through the interface agent. In addition, the change in the direction of the fibers is seen on the fracture surfaces formed after the tensile test.

In Figure 7, where the SEM images of the JPE0 sample are found, the fracture surface of the material with PP film placed between two hybrid HDPE plates is shown. JPE0, ie PP and HDPE raw materials, do not show any fiber structure. It is seen that only 2 different materials are used in terms of morphological structure.

It is clearly seen from the structure that there is no fiber reinforcement SEM images of the JPE1 sample are shown in Figure 7. In these visuals, the breakage surface of the hybrid material with $1.25 \%$ jute reinforced PP film is seen between two hybrid HDPE plates. Fibers are found in JPE1 material. There is no interface adhesion between the fibers and the matrix. The presence of the chemical material is the surface of the polymer material whose structure is altered and elongated. The interface bond is not observed very well.

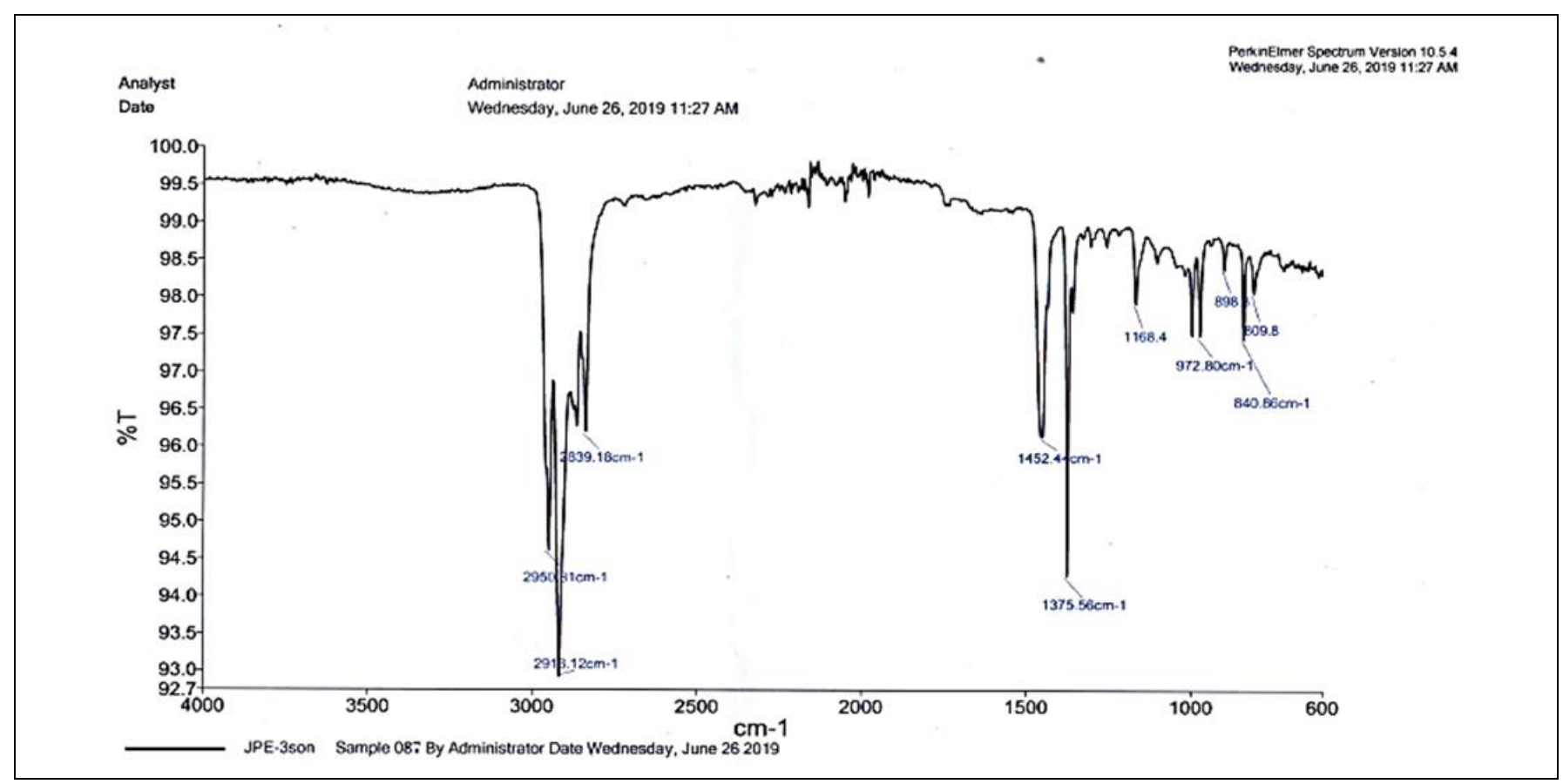

Figure 6. FTIR graph for sample JPE3. 


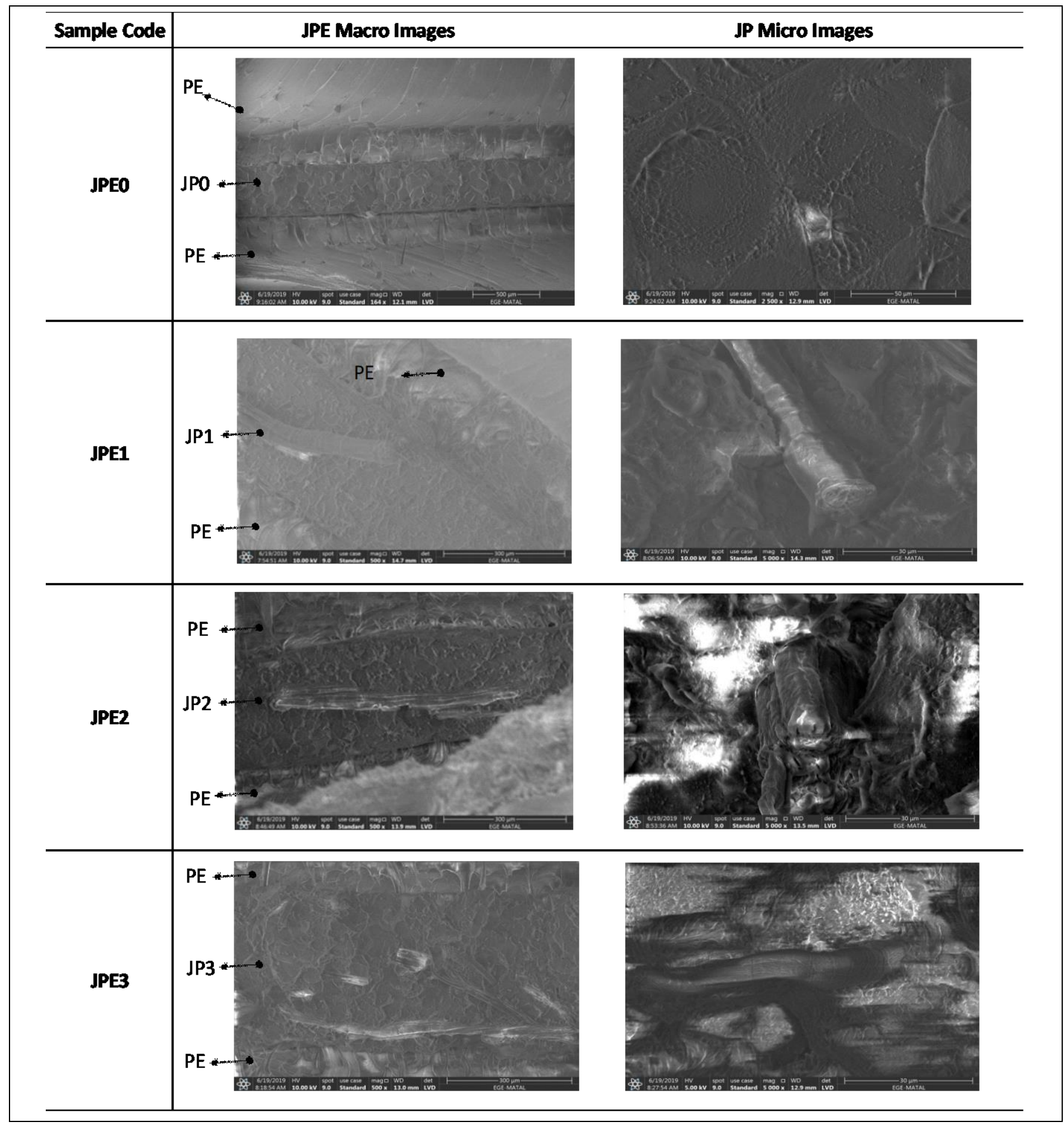

Figure 7. SEM for hybrid materials.

SEM images of the JPE2 sample are shown in Figure 7. In these visuals, the fracture surface of the hybrid material with $2.5 \%$ jute reinforced PP film is placed between two HDPE plates of hybrid structure. There appears to be no good interface adhesion between the fibers and the matrix. JPE2 material has more fiber structure than JPE1. The chemical reaction and adhesion effect between the fiber and the interface seen in JPE2 sample.

SEM images of the JPE3 sample are shown in Figure 7. In these visuals, the fracture surface of the hybrid material with $5 \%$ jute reinforced PP film is seen between two hybrid HDPE plates. Interfacial adhesion between the fibers and the matrix is observed. JPE3 material has the highest jute reinforcement ratio; The fiber multiplicity is clearly seen in Figure 7 compared to the other 3 samples. The sample with the most effective fiber-matrix interface adhesion is JPE3. In this sample, it is noteworthy that the polymer surrounds the fiber well. The presence of interfacial agent is also supported by FTIR results. 


\section{Results and discussion}

In the first stage of the study, in order to determine the mechanical strength of the jute reinforced PP materials, extrusion specimens are produced by injection process. It is observed that tensile samples produced from PP MH 418 type material has an average mechanical strength of $19.8 \mathrm{MPa}$. The maximum mechanical strength is observed with $5 \%$ jute reinforced PP materials. In the first stage, 33\% improvement is achieved in the mechanical strength values of the composite materials. However, in the same material group, the percent elongation values of the material are decreased by $116 \%$.

During determination of density tests, it is found that the density and the reinforcement ratio is inversely proportional. Density reduction provides an alternative for different sectors aiming to reduce weight in different raw material structures used in many areas of industry.

In the second stage of the study, the best mechanical strength value is obtained in JP1 coded $1.25 \%$ jute reinforced PP film material. The average maximum mechanical strength measured at this stage is $27.04 \mathrm{MPa}$. Compared to the original PP MH 418 material, the improvement in the mechanical strength of JP1 materials is $26.7 \%$. In the second stage, increasing jute rates adversely affected the mechanical strength of the material. The improvement in the mechanical strength values of the films produced at this stage are $26.7 \%, 25.4 \%$ and $20.8 \%$ in JP1, JP2 and JP3, respectively. As the film thickness produced in the extrusion decreases, the jute additive in the material adversely affects the mechanical strength of the material. Furthermore, as the reinforcement ratio increased, intermittent fibers are observed in the films taken. As the fiber reinforcement ratio increases, the modulus of elasticity shows that the force it can withstand without plastic deformation is so high and the elastic elongation ratio is so low.

In the third stage of the research, hot press production is realized by placing composite film samples between the HDPE sheets supplied in prepreg form. The maleic anhydride acid is applied with the help of brush between the layers. There is no quality error even though the maleic anhydride acid is used for better adhesion. Although it is expected that the interface adhesion with maleic anhydride acid solution application will improve further; FTIR characterization shows that acidic solution completely disappears and does not form chemical bond due to high temperature effect. When the mechanical strength of the hybrid materials with JPE code is examined, it is seen that the mechanical strength of the material improves as the amount of composite material increases. The highest mechanical strength in composite materials with hybrid structure is measured as $18.41 \mathrm{MPa}$ in JPE3 sample. Increase in mechanical strength is $8.6 \%$ compared to PP MH 418 and 5\% compared to PE S 0464.

To sum up all results:

a) In this study, it has been predicted that the mechanical strength of the hybrid polyolefin materials will be higher. However, manual feeding of the jute additive to the extruder during production causes nonhomogeneous distrubution of fiber in product. This situation negatively affects the film production in the second stage of the research,

b) The mechanical strength values of the samples produced from the same material by different process methods also differ. The mechanical strength values of the products produced by injection method are higher than the products produced by extrusion method. This is in line with Grellmann and Seidler (2015) 's work on PA6 GF 30 material,

c) In the SEM analysis conducted to examine the fracture surfaces after tensile testing, the mechanical strength of the material is negatively affected by the fact that the fiber additives are not distributed homogeneously and some fibers are parallel to the fracture surface,

d) Especially in JPE3 sample with silane process; the pectin and hemicellulose polymers in the fiber are removed to form a rougher fiber surface, resulting in better fiber / matrix adhesion. This improvement in the interface results in the improved mechanical values of silane treated samples. The increase in interface quality, together with the silane process, leads to a better load distribution and a more efficient transfer of the dynamic load from weak matrix to high-strength fibers,

e) According to the density determination, the decrease in density as the jute reinforcement increases in the material indicates that a lightweight material can be produced. Especially, it is an alternative to the production sectors where lightweight and high strength material are in demand,

f) According to FTIR spectra, it is seen that surface treatment is performed and involved in polymerization reaction. However, the presence of maleic anhydride acid can not be seen. Because of working at high temperature; chemical solution is lost in the form of evaporation,

g) When the mechanical values are examined; tensile strength and the reinforcement ratio is inversely proportional. It is interpreted that the short (discontinuous) structure of the jute fibers cause the values to decrease due to the effect on the strength of the material. According to the tensile test results; $11 \%$ reduction is attained in breaking strength compared to the original PP raw material,

h) Compared to PP and PE, the maximum stress of the original material constituting the hybrid structure is $8.6 \%$ of PP MH 418 and $5 \%$ of PE S 0464.

It is observed that the use of an interface agent improves the adhesion between the fiber-matrix interface and the reinforcement of discontinous fiber structure decreases strength and the fiber direction is important. However, it is also observed the mechanical properties improve with polyolefin based composite formed by hybrid composite production. Jute/PP reinforced, polyolefin-based hybrid composites are expected to have the potential to be used in many industries such as automotive and construction, as they are lightweight and robust structures.

As a result, the fracture and deflection of the fibers during the production process adversely affects the mechanical properties. However, the production of hand-made and predominantly thermoset composite materials are labor intensive and there is no recycling of thermoset materials; because they have negative effects in terms of environmental impact.

In the production methods applied in this study, the development of fiber feeding units with automation, the optimization of production processes and the minimization of fiber breakage will enable hybrid composite materials to be used in different fields of industry. 


\section{References}

[1] Arıcasoy 0. "İstanbul Ticaret Odası Kompozit Sektör Raporu”. http://www.ito.org.tr/Dokuman/Sektor/157.pdf (13.07.2019).

[2] Bakkal M and Savaş M. "Cam elyafla güçlendirilmiş doğal elyaf takviyeli kompozitlerin geliştirilmesi”. 3. Ulusal Tasarım Imalat ve Analiz Kongresi, Balıkesir, Turkiye, 29-30 Kasım 2012.

[3] Aggarwal PK, Raghu N, Karmarkar A, Chuahan S. "Jutepolypropylene composites using m-TMI-graftedpolypropylene as a coupling agent". Material and Design 43, 112-117, 2012.

[4] Gakkai NZ and Daikagu Ō. The First Asian-Australasian Conference on Composite Materials: ACCM-1, Page 205, Osaka, Japan, 1998.

[5] Hashmi SAR, Kitano T, Chand N. "Dynamic mechanical behavior of LLDPE composites reinforced with kevlar fibres/short glass fibres". Polymer Composites, 24(1), 49-57, 2003.

[6] Yan L, Chouw N, Jayaraman K. "Flax fibre and its composites". Composites: Part B, 56, 296-317, 2014.

[7] Hong CK, Hwang I, Kim N, Park DH, Hwang BS, Nah C. "Mechanical properties of silanized jute-polypropylene composites". Journal of Industrial and Engineering Chemistry, 14(1), 71-76, 2007.

[8] Zhang Y, Li Y, Ma H ve Yu T. "Tensile and interfacial properties of unidirectional flax/glass fiber reinforced hybrid composites". Composites Science and Technology, 88, 172-177, 2013.

[9] Zadorecki P, Flodin P. "Surface modification of cellulose fibers. II. The effect of cellulose fiber treatment on the performance of cellulose-polyester composites". Journal of Applied Polymer Science, 71, 30-39, 1985.

[10] Felix JM, Gatenholm P, Schreiber HP. "Controlled Interactions in Cellulose-Polymer Composites. I: Effect on Mechanical Properties". Polymer Composites, 14(6), 449-457, 1993.

[11] Ray D, Sarkar BK, Das S, Rana AK. "Dynamic mechanical and thermal analysis of vinylester-resin-matrix composites reinforced with untreated and alkali-treated jute fibres". Composite Science Technology, 62(7-8), 911-917, 2002.
[12] Mohanty AK, Khan MA, Hinrichsen G. "Influence of chemical surface modification on the properties of biodegradable jute fabrics-polyester amide composites". Composites Part A Applied Science and Manufacturing, 31(2), 143-150, 2000.

[13] Gassan J, Bledzki AK. "The influence of fiber-surface treatment on the mechanical properties of jutepolypropylene composites". Composites Part A: Applied Science and Manufacturing, 28(12), 1001-1005, 1997.

[14] Doan TTL, Gao S, Mäder E. "Jute/polypropylene composites I. Effect of matrix modification". Composites Science and Technology, 66(7), 952-963, 2006.

[15] Sain, MN and Kokta BV. "Polyolefin-wood filler composite. I. Performance of m-phenylene bismaleimide-modified wood fiber in polypropylene composite". Journal of Applied Polymer Science, 54(10), 1545-1559, 1994.

[16] Abdelmouleh M, Boufi S, Belgacem MN, Duarte AP, Salah Ben A., Gandini, A. "Modification of cellulosic fibres with functionalised silanes: development of surface properties". International Journal of Adhesion \& Adhesives, 24, 43-54, 2004.

[17] Herrera-Franco PJ, Valadez-Gonzalez A. "Mechanical properties of continuous natural fibre-reinforced polymer composites". Composites Part A Applied Science and Manufacturing 35(3), 339-345, 2004.

[18] Demir Topuk Z. Doğal Lif Takviyeli Eko-kompozitlerde Arayüzeyin Geliştirilmesi. Yüksek Lisans Tezi, Kocaeli Üniversitesi, Kocaeli, Türkiye, 2013.

[19] Sever K. The Role of Interfaces on the Mechanical Performance of Fiber Reinforced Polymer Composites. MSc Thesis, Dokuz Eylül University, İzmir, Turkey, 2009.

[20] Grellmann W und Seidler S. Kunststoffprüfung, 2. Auflage, Seite: 21 und 119, Germany, 2015. 